\title{
MUTUAL ACCOMMODATION OF RELIGIOUS DIFFERENCES IN THE WORKPLACE - A JOSTLING OF RIGHTS*
}

\author{
Radley Henrico \\ BProc LLB LLM \\ Advocate of the High Court of South Africa \\ Senior Lecturer, Public and Procedural Law \\ University of Johannesburg
}

\section{SUMMARY}

In and of itself a constitutional democracy is meaningless. It is the extent to which our rights as individuals in a pluralistic society are given effect and respected that brings to life the constitutionally enshrined values and principles. Religious diversity in a secular society acts as a catalyst of ingredients for conflict in the workplace. Specific legislation has been enacted to give effect to the right against unfair discrimination. Our courts have implemented and interpreted such equality legislation as imposing a duty of accommodation on the employer with regards to the employee's religion.

Our labour-law jurisprudence on transfers of business has recognized a duty of fairness that cuts both ways in favour of the employee and employer. In operational requirement exercises the co-operation of both parties is required. In Canada, a duty of mutual accommodation has been utilized in religious discrimination cases. The current duty of accommodation should be extended to include a duty of mutual accommodation given that religious pluralism is a phenomenon affecting both employee and employer, thus enjoining both parties to engage in realistic measures to embrace diversity.

\section{$1 \quad$ INTRODUCTION}

"The responsibility of tolerance lies with those who have the wider vision."**

Bedevilled with social, economic, political and legal differences ${ }^{1}$ our society, not unlike others, reverberates with the drumbeat of diversity. Differences

* This article is based on aspects of a presentation first delivered by the author at the South African Law Teachers Conference hosted by the Faculty of Law of the Nelson Mandela Metropolitan University, Port Elizabeth from 9-13 July 2012.

** Eliot The Mill on the Floss (1979) Chapter 7.

1 See Albertyn "Constitutional Equality in South Africa" in Dupper and Garbers (eds) Equality in the Workplace: Reflections from South Africa and Beyond (2009) 75 77; Nedumpara Political Economy and Class Contradictions (2004); and Van Apeldoorn, Drahokoupil and Horn Contradictions and Limits of Neoliberal European Governance (2008). 
transposed into diversities lead to discordancy and potential for conflict underscored by the observation that "Contradictions are an essential part of life and never cease tearing one apart". ${ }^{2}$ Life presents us with a moto perpetuo (perpetual motion) of contradictions, as stated by Capulet's "Well, we were born to die!"33 Most vividly is the recent Marikana debacle - such acts of gross, macabre brutality are irreconcilable and intolerable in a constitutional democracy. ${ }^{4}$ Important instruments, addressing diversification in general and religion specifically exist by way of our Bill of Rights ${ }^{5}$ and relevant legislation. ${ }^{6}$ This paper focuses on how the doctrine of reasonable accommodation on the part of the employer should be extended to embrace a notion of mutual accommodation on the part of the employer and employee as a fairer means of adjudicating claims of religious discrimination - it is also dispositive of constructively dealing with the phenomena of pluralism. Employment of mutual accommodation in Canada makes it a suitable international comparator. Furthermore, it is also a country ${ }^{7}$ that has not influenced our jurisprudence insignificantly richly.

\section{RELIGION AND THE WORKPLACE}

\section{Notional definition}

Religion, like spiritual, faith, political, conscientious and belief systems shares the same common denominator - they are subjective and intrinsically personal to the individual or a particular body of persons forming an association. Religious freedom has been aptly described as "perhaps the most personal of human rights, as it goes to the very core of a human being". ${ }^{\prime}$ The freedom to exercise one's faith (religion) in terms of the dictates of its doctrines in a constitutional society based on human dignity, equality, freedom of association and the right to the non-deprivation of property is protected under the auspices of the Bill of Rights chapter ${ }^{10}$ of the South

2 "From a letter [by Nelson Mandela] to Effie Schultz written in Pollsmoor Prison Cape Town, South Africa, 1 April 1987" in Hatang and Venter (eds) Nelson Mandela by Himself: The Authorised Book of Quotations (2011) 65.

3 Wilson The Complete Works of William Shakespeare: The Cambridge Text-Romeo and Juliet Act 3 Scene 4 (1984) 733751.

4 For further reading see Derby "Reflections on Marikana have Asked Little about Lonmin" 6 September 2012 Business Day Live http://www.bdlive.co.za/opinion/columnist/2012.09/06 (accessed 2012-09-06); Author Unknown "Released Mine Workers Greeted by Singing and Dancing" 7 September 2012 The Citizen 3; and Magome "More Mines Shut Down as Strikers Dig in their Heels for Pay Hike" 13 September The Star.

5 Of our 1996 Constitution.

6 See the Employment Equity Act 55 of 1998 (hereinafter "the EEA"); and the Promotion of Equality and Prevention of Discrimination Act 4 of 2000 (hereinafter "PEPUDA").

7 Among other countries like Germany; Australia; France; United States; United Kingdom; and India for example.

8 See Lolllini "The South African Constitutional Court Experience; Reasoning Patterns" 2012 Ultrecht LR 5568 fn 57 esp 72 fn 66; and O'Cinneide "The Right to Equality: A Substantive Legal Norm or Vacuous Rhetoric?" 2008 University College of London Human Rights Review 78 87-88 fn 88.

9 Thames "Mechanisms for Religious Freedom Advocacy" 2011 International Journal for Religious Freedom 115116.

10 Two (s 7-39). 
African Constitution (the Constitution). ${ }^{11}$ Direct provision is made for the right to religion, its expression and association. ${ }^{12}$ In parity of reasoning, the right not to be religious; to be atheistic or agnostic is a belief equally deserving of protection. The manifestation of religion plays itself out in private ${ }^{13}$ as well as public spheres. ${ }^{14}$

Establishing whether a proscribed act ${ }^{15}$ has occurred requiring legal redress is often reliant on a legal definition, ${ }^{16}$ alternatively, an interpretation of facts and circumstances conducing to a legal conclusion. This aligns itself with a basic tenet of the rule of law that all citizens ${ }^{17}$ are entitled to foreknowledge of the law. ${ }^{18}$ The extent to which religion ${ }^{19}$ lends itself (un)favourably as the subject matter of a definition or an open-ended interpretation is largely determined by the limitation(s), if any, that can be attached to its scope and meaning.

Certain definitions are satisfactorily replete to leave no doubt concerning their meaning or purpose. ${ }^{20}$ Religion, however, as a term is intensely contextually complex in its depth and breadth of meaning. Its elasticity allows it to permeate the confines of a rigidified definition. To be understood and applied constructively in disputes involving discrimination it is submitted that an open-ended casuistic, judicial, interpretive approach of "balancing competing fundamental rights and freedoms ${ }^{\prime 21}$ is required. Aside from extant case authority, ${ }^{22}$ there will be an exponential jurisprudential development of

111996.

$12 S 9(3)$ of the equality provision in the Bill of Rights proscribes unfair discrimination on the basis of religion; s 15(1) provides everyone with the right to freedom of "conscience, religion, thought, belief or opinion"; s 18 provides everyone with the right to freedom of association; and $s 31$ (1) provides that persons belonging to a religious community may not be denied the right, with other members of the community to practise their religion and form, join and maintain religious associations and other organs of civil society. Because these rights are not self-executing, provision for the realization thereof has been catered for in other forms of legislation such as the Labour relations Act 66 of 1995 (the LRA); EEA; PEPUDA and the Promotion of Administrative Justice Act 3 of 2000 (hereinafter "PAJA").

13 Domestic activities dedicated to specific religious tenets.

14 Eg: The celebration of Good Friday and the commercial selling of Easter eggs in celebration of the Easter period is a Christian faith manifestation as is the period of Ramadan, the ninth month of the Muslim year celebrated by fasting from sunrise to sunset. Significantly, the portrayal of the words "SOLI DEO GLORIA" on the 2009 South African one rand coin inclines to the notion, it is submitted, of "God" in the Christian sense.

15 References to acts in this regard are to include conduct by way of omission.

16 In terms of a specifically worded or open-ended concept.

17 Personal and corporate.

18 Bingham The Rule of Law (2010) 39.

19 As a concept, belief, notion or practice.

20 An example may be the term "auditor" which is defined in s 213 of the LRA as meaning "any person who is registered to practise in the Republic as a public accountant and auditor".

21 S v Makwanyane 1995 (3) SA 391 (CC) par 302. See also Klare "Transformative Constitutionalism and the Common and Customary Law" 2010 SAJHR 403; Amoah and Bennett "The Freedoms of Religion and Culture Under the SA Constitution: Do Traditional African Religions Enjoy Equal Treatment?" 2008 Journal of Law and Religion 1 14-15; and Du Plessis and De Ville "Bill of Rights Interpretation in the South African Context (3): Comparative Perspectives and Future Prospects" 1993 Stellenbosch LR 356. 
the term, which will also be informed by guidelines offered in terms of the South African Charter of Religious Rights and Freedoms (the SACRRAF). ${ }^{23}$

Although no universal definition exists for religion; the debate concerning what comprises religion is universal. ${ }^{24}$ Conversely, does an individual, society or body of persons (an association) that is not "religious" fall to be described as being secular? ${ }^{25}$ The multi-diversity of debate on what constitutes religion ${ }^{26}$ as opposed to secularism attracts closer analysis given that both terms are material to the question of the basis upon which differentiation takes place. Added to such complexities are issues such as the extent to which individuals of the same faith or belief may vary in degrees of compliance with the tenets of their religion. ${ }^{27}$ Is an individual more compliant with her faith more deserving of protection in terms of equality provisions than one who is less compliant? Should differentiation occur, if so, on what basis for it to be considered fair? These are some of the issues our courts are called upon to make value-laden judgments. To what degree should the religion or the religious belief manifest itself on the part of the individual or association before a legally valid allegation is made of unfair treatment?

\section{Workplace concerns}

Discrimination based on religion in the workplace is of particular concern given the importance of striving to achieve a harmonious working environment ${ }^{28}$ and the fact that work is an unavoidable means and need for

22 See, eg, Prince $v$ President, Cape Law Society 2002 (2) SA 794 (CC) par 40; MEC for Education, Kwazulu-Natal v Pillay 2008 (1) SA 747 (CC) par 46 and 92; Department of Correctional Services v POPCRU 2011 ZALAC 21 par 24-26; and Kievits Kroon Country Estate $v$ CCMA 20113 BLLR 241 (LC).

23 Signed at the University of Johannesburg, Gauteng, South Africa on 21 October 2010. See especially clauses 1,3 and 7 of the SACRRAF.

24 See Wald "Religion and the Workplace: A Social Science Perspective" 471477 http://www.law.illinois.edu/publications/clipj/archive/vol_30/issue_3/waldarticle30-3.pdf (accessed 2011-09-28); Supoit "Orare/Labore" 641645 http:www///.iea-nantes.fr/fichier/ plug_download/3542/download_fichier_fr_orare_jcll.pdf (accessed 2011-09-28); and Gunn "The Complexity of Religion and the Definition of 'Religion' in International law' Harvard Human Rights Journal http://ww.law.harvard.edu/students/orgs/hrj/iss16/ gunn/shtml.pdf (accessed 2011-10-01). Eg, does religion reach beyond traditional belief in a divine being or deity to include other philosophical beliefs on issues such as death, life, morality and lifestyle choices, eg, pacifism or atheism) - see Watson EU Social and Employment Law Policy and Practice in an Enlarged Europe (2009) 494. See also Quinn "Introduction: The Understandable, but Misguided, Quest for a Legal Definition of 'Religion'" http://www.law.harvard.edu/students/orgs/hrj/iss16/gunn.shtml (accessed 2011-01-10).

25 See Benson "The Case for Religious Inclusivism and the Judicial Recognition of Religious Associational Rights: A Response to Lenta" 2008 Constitutional LR 297 300; Ferrari and Cristofori Law and Religion in the $21^{\text {st }}$ Century: Relations between States and Religious Communities (2010); and Van der Vyver "Law and Religion" in Van der Vyver (ed) Seven Lectures on Human Rights (1976) 3552.

26 See Cox "Religion without God: Methodological Agnosticism and the Future of Religious Studies" 15 and 7 http://ww.thehibbertrust.org.ik/documents/hibbert_lecture_2003.pdf (accessed 2011-10-01).

27 Benson 2008 Constitutional LR317.

28 Kalula "Discrimination and Fundamental Human Rights in Africa: Is 'Discrimination Law' Doing the Job it is Supposed to Do?" http://www.ia/snet.org/meetings/labour/papers/Kalula- 
one to earn a living. Discrimination against an employe $e^{29}$ by an employer, or any other person, based on religion is principally regulated by the legislative provisions of the EEA. ${ }^{30}$ Mere mention of the word "discrimination" tends to pique our senses into automatically considering same to be unfair. ${ }^{31}$ Plurality of religion induces one to consider more than the stereotypical discrimination perpetrated by an employer against a worker. Some additional issues arising therefrom are:

- Discrimination and / or unfair labour practices between workers themselves;

- discrimination by a worker against the employer or employer organization;

- how employer organizations justify excluding workers, including applicants for employment, not of the same religious faith;

- tests our courts apply when adjudicating religious discrimination disputes; and

- the importance of consistency in the application of tests to consider justifications to a claim of unfair discrimination.

\section{Equality in the workplace}

Equality in the context of South African ${ }^{32}$ law draws heavily on a history marked by human rights violations where basic entitlements and benefits were withheld from persons on capricious grounds of race, culture, gender or sexual orientation. Discrimination based on race, which was once most prolific $^{33}$ now reveals itself in various manifestations, including, but not limited to religion. Reference to equality gives rise to diverse opinions on its

South\%20Africa.pdf (accessed 2012-09-06); and Ghai "Decent Work: Objectives and Strategies Work" (International Labour Office - Geneva) International Institute for Labour Studies 200611 http://www.oit.org/public/english/bureau/inst/download/decentghai.pdf (accessed 2012-04-08).

29 The term "employee" will, for ease of reference, be substituted with the term "worker" which includes, but is not limited to, permanent workers, applicants for employment, casual labourers, persons presumed and deemed to be employees, casual, temporary and parttime employees as well as illegal immigrant workers. See Van Niekerk, Christianson, McGregor, Smit and Van Eck Law@work (2011) 59-81. See s 5 of the LRA which deals with protection against discrimination to employees and persons seeking employment for exercising any right conferred by the LRA. See also SANDU v Minister of Defence 199920 ILJ 2265 (CC); and Wyeth SA (Pty) Ltd v Manqele 20056 BLLR 523 (LAC).

30 In terms of $s$ 6(1).

31 The cause of which, it is submitted, can be attributed to our historical milieu of inherent injustices perpetrated on different cultures and people of our society. See Brink $v$ Kitshoff 1996 (6) BCLR 752 (CC) par 40.

32 Inclusive, but not limited to such disciplines as Labour; Constitutional; Human Rights; and Administrative law.

${ }^{33}$ Currie and De Waal The Bill of Rights Handbook 5ed (2005) 231. Interestingly, discrimination on the basis of gender and race in industrial council agreements was outlawed by s 24(2) of the Labour Relations Act 28 of 1956 and s 19(6) of the Wage Act 5 of 1957. See Du Toit et al Labour Relations Law: A Comprehensive Guide (2003) $541 \mathrm{fn} 2$; and see also President of the RSA v Hugo 1997 (4) SA 1 (CC). 
meaning ${ }^{34}$ as well as that of the concept of fairness. ${ }^{35}$ Treating all persons equally as a measure of ensuring fairness is a potential recipe for disaster in a heterogeneous society demanding fair treatment as opposed to equal or same treatment. ${ }^{36}$ Since formal equality emphasizes form above substance, the outcome may not always be fair. What is required rather is not equal treatment for all, but treating people fairly ${ }^{37}$ in accordance with either specific needs or requirements of the employee or the employer. The learned authors Van Niekerk et al refer to "people who are similarly situated should be treated similarly, and people who are not similarly situated should not be treated alike". ${ }^{38}$ Treating everyone in the same manner in respect of heterogeneity may well result in unfair unequal treatment and a violation of human dignity. ${ }^{39}$ Allowance must be made to treat different people differently, for reasons that are fair and in a manner consonant with regard to their status and worth as human beings.

Accordingly, the notion of substantive equality is one which is applied in favour of formal equality on account of the fact that it acknowledges differences ${ }^{40}$ that require appropriate treatment in terms of certain norms and values. ${ }^{41}$ Equality relies for its life-blood on the right to human dignity, ${ }^{42}$ stated by O'Regan $\mathrm{J}$ as "[...] the intrinsic worth of human beings: human beings are entitled to be treated as worthy of respect and concern ...,43 Human dignity is a social value attached to human beings acknowledging their autonomous self-worth, ${ }^{44}$ thereby forming an inexorable ingredient of

${ }^{34}$ Langa "Transformative Constitutionalism" 2006 Stell LR 351.

35 Author Unknown "The Ideas of Equality and Non-discrimination: Formal and Substantive Equality" http://www.equalrightstrust.org/ertdocumentbank/The\%20ldeas $20 \%$ of\%Equality\% 20\%and\%20Non-discrimination (accessed 2012-03-14). See also Moseneke "The Fourth Bram Fischer Memorial Lecture - Transformative Adjudication" 2002 SAJHR 309.

36 Take the example of an equal number of parking bays being made available for disabled persons as there are for able-bodied persons is a far cry from addressing the actual needs of the disabled substantively. See Cooper "The Boundaries of Equality in Labour Law" 2004 ILJ 813816.

37 As opposed to capriciously or arbitrary.

38 Van Niekerk et al Law@work 121.

39 See Pitt "Keeping the Faith: Trends and Tensions in Religion or Belief Discrimination" 2011 ILJ 384385.

40 On account of, eg, personal or socio-economic circumstances.

41 President of the RSA v Hugo supra par 44; and Van der Merwe v Road Accident Fund 2006 ZACC 4 par 48. An example would be an international airline carrier which provides on board food for all its cabin-crew members. Formal equality would require that all cabin-crew members be provided with food since to withhold food from one or some on an arbitrary ground would be unfair. Substantive equality would require something more than mere equal treatment by virtue of the provision of food per se. It would require that account be taken of the different religious beliefs of the cabin crew members and that food be catered in accordance with each member's religious beliefs. As such they are not treated equally; they are equally deserving of food regard being had to their religious belief system(s).

42 Provided for in $s 10$ of the Constitution. See Fredman "Facing the Future: Substantive Equality Under the Spotlight" in Dupper and Garbers (eds) Equality in the Workplace: Reflections from South Africa and Beyond (2009) 19.

${ }^{43}$ Currie and De Waal The Bill of Rights Handbook 274 with reference to the decision of $S v$ Makwanyane.

44 See Woolman "The Widening Gyre of Dignity" in Woolman and Bishop (eds) Constitutional Conversations (2008) 193 212-215. See also Bato Star Fishing v Minister of Environmental Affairs 2004 (4) SA 490 (CC) par [73]-[75]; and Albertyn and Goldblatt "Towards a 
the right to equality in the substantive sense. ${ }^{45}$ Alternatively, it may be used to galvanize non-arbitrary treatment measures. ${ }^{46}$ This much can be deduced from the obiter statement by Basson $\mathrm{J}$ that: "[The] right to dignity is seriously impaired due to the unfair discrimination."

Freedom of association ${ }^{48}$ is an underpinning right to the right to equality ensuring that all individuals may make unfettered choices as to the manner in which they live their lives. It is a right through which equality, as well as dignity, is asserted not only to exercise a particular religious belief but also to transcend an individual status and become members ${ }^{49}$ of associations through which rights and interests are effectively exercised as a collective. ${ }^{50}$ When addressing religious pluralism and the balancing of competing rights and interests it is important to keep in mind that this is addressed optimally in terms of substantive equality as opposed to formal equality. ${ }^{51}$

\section{Workplace discrimination}

Everyone has a constitutional right to fair labour practices. ${ }^{52}$ This has been interpreted to apply as much to the employer as it does the employee. ${ }^{53}$ The constitution purports to endorse a formal equality concept by providing that everyone is equal before the law and has the right to equal protection and benefit of the law. ${ }^{54}$ However, the express constitutional provision that no person may discriminate unfairly directly or indirectly against another ${ }^{55}$ clears the path to allow for instances of differentiation arising wherein

Substantive Right to Equality" in Woolman and Bishop (eds) Constitutional Conversations (2008) 231234.

45 See Garbers "Proof and Evidence of Employment Discrimination under the Employment Equity Act 55 of 1998" 2000 SA Merc LJ 136; Dupper "The Current Legislative Framework" in Dupper (ed) Essential Employment Discrimination Law (2004); McCrudden "Human Dignity and Judicial Interpretation of Human Rights" 2008 European Journal of International Law 655685 and 724; and Fagan "Dignity and Unfair Discrimination: A Value Displaced and A Right Misunderstood" 1998 SAJHR 220. Cf Albertyn and Goldblatt "Facing the Challenge of Transformation: Difficulties in the Development of an Indigenous Jurisprudence of Equality" 1998 SAJHR 248 254; and De Waal "Equality and the Constitutional Court" 2002 SA Merc LJ 141150.

46 See Meyerson Rights Limited (1997); Réaume "Discrimination and Dignity" 2003 Louisiana $L R$ 1; Grant and Small "Disadvantage and Discrimination: The Emerging Jurisprudence of the South African Constitutional Court" Northern Ireland Legal Quarterly 172; and Cooper "A Constitutional Reading of the Test for Unfair Discrimination in Labour Law" 2001 Acta Juridica 121129.

47 Strydom v Nederduidse Gereformeerde Gemeente Moreleta Park 2008 ZAEQC 1 par 25.

48 Provided for in $\mathrm{s} 18$ of the Constitution.

49 Or refrain therefrom.

50 Premised on the assumption that the purpose of such associations is lawful. See also Currie and De Waal The Bill of Rights Handbook 424; and SANDU v Minister of Defence 2007 ZACC 10 par 8.

51 See Du Toit "The Evolution of the Concept of 'Unfair Discrimination' in South African Labour Law" 2006 ILJ 13111335 and 1337-1339.

$52 S 23(1)$. See also the provisions of $s 5$ and 6 of the LRA which seek to protect the right to freedom of association of both employer and worker.

53 NEHAWU v University of Cape Town 20035 BLLR 409 (CC).

$54 \mathrm{~S} 9(1)$.

55 S $9(4)$. 
treating somebody differently is actually not unfair. ${ }^{56}$ The inference is that, if differentiation was not permitted and equal treatment was simply administered, such equal treatment would have been unfair. An example is where no differentiation is made between the type of treatment given to HIVAIDS and Tuberculosis patients on the basis that in both instances one is dealing with patients who must be treated equally through administering an aspirin. Fairness demands that we differentiate in the type of treatment. In Van Der Linde, the court found that the essence of equality lies not in treating everyone in the same way, but in treating everyone with equal concern and respect. ${ }^{57}$ The mere differentiation of people is therefore not necessarily considered to be unfair discrimination; a substantive schism is required.

\section{RELIGIOUS RIGHTS FRAMEWORK}

\section{Fundamental and legislative rights}

Our democratic state is premised on the express provision of the supremacy of the Constitution and the rule of law. ${ }^{58}$ These imperatives charge our judges with interpreting legislation through a value-laden prism. ${ }^{59}$ The transformation of South Africa from an oppressive regime ${ }^{60}$ to a rights-based order obliges such an interpretation. That "[E]veryone is equal before the law and has the right to equal protection and benefit of the law"61 is buttressed by the fact that neither the state nor any person may "unfairly discriminate directly or indirectly against anyone $[\ldots]^{62}$ on the basis of religion." ${ }^{33}$ National legislation to "prevent or prohibit unfair discrimination" 64 is expressly required to provide statutory mechanisms to give expression to the capacious notions of the protection of equality which are not self-executing. This fulfils a twofold purpose. First, it provides the necessary framework giving effect to the prohibition against unfair discrimination. Second, it enables persons who have been discriminated against unfairly on the basis of religion a means by which to formulate their cause of action against the transgressor.

\footnotetext{
56 Albertyn and Goldblatt 1998 SAJHR 249-250; and Freedman "Understanding the Right to Equality" 1998 SALJ 243251.

571997 (3) SA 1012 (CC) par 32-33. See also Albertyn in Dupper and Garbers Equality in the Workplace 75 77-78.

58 S 1 (c). For further reading on the rule of law see Bingham The Rule of Law (2011); and Costa and Zola The Rule of Law: History, Theory \& Criticism (2007).

59 Hoexter Administrative Law in South Africa (2012) 18 and the authorities referred to at fn 17 and 18. Also see s 165 (3) of the Constitution.

60 Currie and De Waal The Bill of Rights Handbook 231-232.

${ }^{61} \mathrm{~S} 9(1)$.

62 S 9 (3) and (4).

${ }^{63}$ Religion is one of seventeen grounds of discrimination referred to and listed in subsection (3). Since accommodating religious diversity is the basis of this paper, focus on the other grounds of discrimination falls outside the ambit of this paper.

64 In terms of $s 9(3)$.
} 


\section{Equality in terms of the EEA}

The EEA aims at achieving equity in the workplace by promoting equal opportunity and fair treatment through eliminating unfair discrimination and implementing affirmative action measures. ${ }^{65}$ Conceptually, unfair discrimination implies instances where one encounters "fair" discrimination. Understandably, discrimination or differentiation per se can be benign. ${ }^{66}$ Contextualization is peremptory. On the one hand we have bad or unfair (derogatory, pejorative, adverse, prejudicial) conduct rendering differentiation unfair and on the other hand, good or fair (with reference to principles giving effect to values necessary to realize a particular individual's needs) conduct rendering the differentiation fair. We need therefore first to decide whether differentiation or preferential treatment has taken place before we turn our attention to consider whether it is fair or unfair.

Express provision is made by the EEA for the elimination of unfair discrimination $^{67}$ and the prohibition of unfair discrimination. ${ }^{68}$ Two circumstances $^{69}$ are listed when it is not unfair to discriminate. ${ }^{70}$ It has been pointed out that South Africa is distinguishable for confining discrimination to a legal definition, ${ }^{71}$ as borne out by our legislation, ${ }^{72}$ that refers to "unfair discrimination". This manifestation appears to have its origins in the development of the unfair labour-practice jurisprudence of the Industrial Court, which culminated in "unfair discrimination" being reflected in our legislation. ${ }^{73}$ Interpretation of the $\mathrm{EEA}^{74}$ must be in compliance with the Constitution, ${ }^{75}$ taking into account any relevant code of good practice used in the EEA or any other Act, ${ }^{76}$ and comply with any international obligations of the Republic, in particular the ILO Convention (No. 111) ${ }^{77}$ concerning Discrimination in respect of Employment and Occupation $(C$ 111). Discrimination is defined by Article 1 of Convention 111 as:

"(a) any distinction, exclusion or preference made on the basis of race, colour, sex, religion, political opinion, national extraction or social origin, which has

65 2(a) and (b).

66 See Prinsloo v Van der Linde 1997 (3) SA 1012 (CC) par 24-26.

$67 \mathrm{~S} 2(\mathrm{a})$ and 5.

${ }^{68} \mathrm{~S} 6(1)$

69 Namely, affirmative action measures consistent with the purpose of the EEA and discrimination on the basis of the inherent requirement of the job.

70 S 6(2)(a) and (b).

71 Du Toit "The Prohibition of Unfair Discrimination: Applying Section 3(d) of the Employment Equity Act 55 of 1998" in Dupper and Garbers (eds) Equality in the Workplace: Reflections from South Africa and Beyond (2009) 139142.

72 Per the above referred to sections of the EEA. See also s 9(3)-(5) of the Constitution; s 6 of PEPUDA; and $s$ 187(1)(f) of the LRA.

73 In terms of the Labour Relations Amendment Act 83 of 1988 per Du Toit in Dupper and Garbers Equality in the Workplace 142.

74 S 3(a).

75 Ibid.

$76 \mathrm{~S} 3(\mathrm{c})$.

77 In respect of which South Africa was a signatory.

78 S 3(d). 
the effect of nullifying or impairing equality or opportunity or treatment in employment or occupation;

(b) such other distinction, exclusion or preference which has the effect which has the effect of nullifying or impairing equality of opportunity or treatment in employment or occupation as may be determined by the Member concerned after consultation with representative employers' and workers' organisations, where such exist, and with other appropriate bodies".

Article 1(a) endorses the notion of substantive equality and human dignity. ${ }^{79}$ An exercise of balancing of fundamental rights, it is submitted, must be executed subject to the rule of law and its derivatives, such as rationality, good faith, proportionality, reasonableness and fairness. Nonself-executing provisions of the Constitution, namely $s 9$ resulted in the EEA, as with the LRA. ${ }^{80}$ However, PEPUDA is the legislation utilized in nonworkplace-discrimination disputes.

Criticism has been leveled against the manner in which our courts have inconsistently and incorrectly dealt with discrimination disputes under sanctuary provided for a discrimination test as set out in Harksen $v$ Lane $N O .^{81}$ Both the EEA and LRA are enabling legislation and in the interests of the principle of subsidiarity must be relied upon in discrimination-workplace disputes without bypassing ${ }^{82}$ same and relying directly on section 9 of the Constitution. ${ }^{83}$ The fact that both Acts are obliged to give effect to Convention 111 also provides our courts with essential guidelines when dealing with religious discrimination disputes. ${ }^{84}$

It is submitted that the argument advanced by $\mathrm{Du}$ Toit in this regard is cogent and coherent. However, further critical analysis and evaluation thereof will be in order to establish:

- The congruency between the reasonable accommodation concept as defined in section 1 of the EEA and the provisions of Convention 111 taking into account that no right is absolute; ${ }^{85}$ and

- the extent to which Convention 111 addresses claims, defences and limitations on the exercise of rights adequately. ${ }^{86}$

Emphasis is placed on analyzing the EEA and LRA as the appropriate legislative framework due to their relevance to Labour Law. Clearly, to the

79 Albertyn in Dupper and Garbers Equality in the Workplace 88; and obiter remarks by Moseneke $J$ in Minister of Justice $v$ Van Heerden 20046 SA 121 (CC) par 27 per Albertyn in Dupper and Garbers Equality in the Workplace 80.

${ }^{80}$ With reference to $s 23$ of the Constitution dealing with the right to fair labour practices. It is submitted that the automatic unfair dismissal provisions of $s 187$ of the LRA give effect to $s 9$ of the Constitution.

811998 (1) SA 300 (CC).

82 See Sidumo v Rustenburg Platinum Mines Ltd 2007 ZACC 22 par 101; and Gcaba v Minister of Safety and Security 2009 ZACC 26 par 56. Cf Van der Walt "Normative Pluralism and Anarchy: Reflections on the 2007 Term" 2008 Constitutional LR77 105 and 127.

83 Du Toit et al Labour Relations Law 151 referring to the cases of SANDU par 123; and Minister of Health $v$ New Clicks 20061 BCLR 1 (CC) par 437.

84 Du Toit et al Labour Relations Law 154 and the authorities cited at fn 59.

85 Currie and de Waal The Bill of Rights Handbook 163.

86 Hepple "The Aims and Limits of Equality Laws" in Dupper and Garbers (eds) Equality in the Workplace: Reflections from South Africa and Beyond (2009) 329. 
extent that the Constitution is the supreme law of the land, ${ }^{87}$ the aforesaid Acts, and ancillary legislation must give effect to any constitutional obligations and principles that have come to bare their own influences or limitations contained elsewhere in the Bill of Rights, ${ }^{88}$ the rule of law, ${ }^{89}$ the manner in which religious observances may be conducted at state or stateaided institutions, ${ }^{90}$ the manner in which freedom of expression may be exercised $^{91}$ and the reasonable accommodation or tolerance of religious beliefs.

\section{Equality in terms of the LRA and dispute resolution}

Upholding fundamental labour-law rights ${ }^{92}$ inclusive of the right to fair labour practices is an express purpose of the LRA. ${ }^{93}$ As previously stated, the right to fair labour practices is equally applicable to both employer and worker alike. ${ }^{94}$ Unfair labour practices are currently codified in terms of the LRA. ${ }^{95}$ The question arises whether such codification conduces to undue regularization and compartmentalization. The current remedy offered in the form of an automatically unfair dismissal arising from an unfair discrimination based on religion ${ }^{96}$ (the prohibition on dismissal based on discrimination in the LRA is read with the prohibition on discrimination in section 6 of the EEA) offers only the employee protection. No framework in terms of the above Acts is provided for to address a situation where, for example, there exists religious discrimination by an employee against an employer. The most appropriate way for this to have been addressed, it is submitted, would be in terms of permitting such conduct to constitute an unfair labour practice.

Determination of religious discrimination disputes is usually adjudicated in the Labour Court. ${ }^{97}$ Any cost incentive which may induce the parties to agree to the jurisdiction of the Commission for Conciliation, Mediation and

$87 \mathrm{~S} 1(\mathrm{c})$.

88 S 7(3). See also National Coalition for Gay and Lesbian Equality v Minister of Justice 1999 (1) SA 6 (CC). One such limitation that could be imposed on an expression of one's right to religious belief in the workplace may be the very conflict of freedom of expression with another fundamental right such as freedom of association. An example would be an official spiritual office bearer of the Anglican church, employed in such capacity by the church who has a sudden change of heart and converts to Catholicism but insists on retaining his current post without relinquishing his newly-found religious belief system.

$89 \mathrm{~S} 1(\mathrm{c})$.

$90 \mathrm{~S} 15(2)(\mathrm{a})-(\mathrm{c})$.

$91 \mathrm{~S}$ 16(2).

92 Such as the right of every worker to form and join a trade union and participate in its activities and programmes and every employer having the right to form and join an employers' organization and to participate in the activities and programmes of such organization.

$93 \mathrm{~S} 1$ (a). Reference to $\mathrm{S} 27$ of the Constitution is to the section in the Constitution of the Republic of South Africa 200 of 1993, which was the forerunner of $s 23(1)$ of the Constitution.

94 NEHAWU.

$95 \mathrm{~S} 186(2)(\mathrm{a})-(\mathrm{d})$.

$96 \mathrm{~S} 187(1)(\mathrm{f})$.

97 In terms of $s$ 191(5)(b)(i) of the LRA and $s 10(6)(a)$ of the EEA parties agree to the jurisdiction of the CCMA. 
Arbitration (the CCMA) ${ }^{98}$ is often dissipated by the perceived inexperience or ineptitude of the commissioners. Alternatively, the respondent party may unnecessarily simply withhold consent to arbitration before the CCMA. Discrimination claims are by their nature complex, thus warranting referral to the Labour Court for adjudication. Formal litigation has cost implications placing claimants at a potential disadvantage. ${ }^{99}$ It does not automatically follow that a claim adjudicated in the Labour Court will per se yield greater success. A well-seasoned commissioner seized with a discrimination arbitration at the CCMA may indeed bring to the matter a richer and more mature finding than a recently appointed inexperienced judge of the Labour Court. To enhance the understanding and complexities pertaining to discrimination claims and disputes it is submitted that a code of conduct relating to religious discrimination should be drafted. This can serve as a guide to those called upon to arbitrate or adjudicate religious discrimination disputes.

Davies gives an assessment of an economist versus a rights-based theory that should be taken into account when addressing religious discrimination in the workplace. ${ }^{100}$ Does a costly regulatory intervention of a rights-based legal framework ${ }^{101}$ outflank an unregulated, flexible approach where discrimination is left to be addressed by elusive "market forces"? It is submitted that in the context of our constitutional dispensation a laissez-fair approach cannot be tolerated.

The Codes of Good Practice on Picketing, ${ }^{103}$ Handling of Sexual Harassment ${ }^{104}$ and Dismissal Based on Operational Requirements ${ }^{105}$ (the Codes) ${ }^{106}$ serve as examples the contents whereof provide insightful guidelines. Whilst the Codes may not be regarded as hard law, they offer guidelines and assistance in arriving at an informed decision. Adoption of the SACRRF on 21 October 2010 was a step in the direction of acknowledging the extent to which religious discrimination requires codification. Regrettably, it lacks the legal status of any of the Codes. ${ }^{10}$

98 In terms of $s$ 10(6)(b) of the EEA.

99 Who are financially unable to have their claim adjudicated in the Labour Court and would instead settle for the CCMA despite the aforementioned shortcomings, but are precluded from doing so by the withholding of the consent to jurisdiction by the opponent.

100 Davies Perspectives on Labour Law 2ed (2009) Chapter 7 118-138.

101 In terms of which rights are enforced and obligations monitored.

102 Regard had to our history of trenchant inequality. See Benson 2008 Constitutional LR 298; see Kalula 4 in fn 28 above; Albertyn in Dupper and Garbers Equality in the Workplace 81. See also Hepple in Dupper and Garbers (eds) Equality in the Workplace 29.

${ }^{103}$ Published under GN 765 in GG 18887 of 1998-05-15; and Part B of the Schedule of the LRA.

104 Published under GN 1367 in GG 19049 of 1998-07-17; and Part B of the schedule of the LRA.

${ }^{105}$ Published under GN 1517 in GG 20254 of 1999-07-16; and Part B of the Schedule of the LRA.

${ }^{106}$ Which appear as Schedules to the LRA.

${ }^{107}$ Nothing precludes a commissioner or judge having regards to the content of the SACCRF. 


\section{4 \\ ADDRESSING RELIGIOUS DISCRIMINATION IN THE WORKPLACE}

\section{Current prohibitions on religious discrimination}

Unfair discrimination ${ }^{108}$ infringes both principles of equality ${ }^{109}$ and human dignity. ${ }^{110}$ Our law deals with religious discrimination in the workplace in terms of the statutory framework of the EEA and LRA. ${ }^{111}$ The EEA expressly prohibits unfair discrimination on nineteen (19) listed grounds. ${ }^{112}$ An example would be an employer who gives salary increases to all workers save a Muslim worker on the basis that the employer is prejudiced against the Islamic faith as a religion.

Proof of religious discrimination would be required to take place as follows: First, the Muslim worker has the burden of proving that the reason he did not receive a salary increase was because he is a Muslim. This amounts to differentiation. A second requirement is that the differentiation amounts to unfair discrimination which in turn has two enquiries, namely whether it is on a specified listed ground or an unlisted ground based on "attributes and characteristics which have the potential to impair the fundamental human dignity [of the worker as a human being or affect him] adversely in a comparably serious manner"113 and then to enquire as to whether the differentiation amounts to unfair discrimination. ${ }^{114}$ Should the court find that discrimination took place on a listed ground, unfairness is presumed, ${ }^{115}$ however, if on an unlisted ground then the worker must go one step further in proving the unfairness of the discrimination. ${ }^{116}$ Religion is one of the listed grounds in section 6(1) and discrimination based on religion is thus presumed to be unfair. Neither direct nor indirect discrimination has been defined by the EEA or any other legislation in our law. The meaning of

${ }^{108}$ On account of arbitrary, prejudicial treatment or stereotyping individuals on the basis of, inter alia, race, gender, sexual orientation, age, disability or religion.

${ }_{109}$ Minister of Education $v$ Syfrets Trust 2006 (4) SA 25 (CC) par 30.

${ }^{110}$ Ferrari and Cristofori Law and Religion in the $21^{\text {st }}$ Century 30-31. See also Guest "The Role of Moral Equality in Legal Argument" in Du Bois (ed) The Practice of Integrity: Reflections on Ronald Dworkin and South African Law (2008) 18 22-25.

111 This is not to the exclusion of a private dispute relating to religious discrimination in the workplace that may arise between co-workers which would either be dealt with in terms of a disciplinary hearing, alternatively more formally in terms of the provisions of PEPUDA, the latter of which will not fall within the scope of the this research.

112 S 6(1).

${ }^{113}$ See Harksen $v$ Lane NO 1998 (1) SA 300 (CC) as set out and the test discussed in Van Niekerk et al Law@work 134-135. An example of indirect or disparate discrimination would be where facially it would appear that the employer is treating all the workers equally by providing a food canteen at the workplace. However, in so far as the canteen fails to cater for halaal food in respect of Muslim workers, the end result is that such failure has the potential to impair the fundamental human dignity of [Muslim persons] as human beings or to affect them adversely in a comparably serious manner. See also $S$ v $S 2010$ ZAWCHC 212 par [27]; and Mvumvu v Minister of Transport 2011 ZACC 1 par 25.

114 Van Niekerk et al Law@work 135 and authorities cited at fn 66-68.

${ }^{115} \mathrm{~S} 11$ of the EEA.

116 Ibid. 
both terms has been developed by our courts. ${ }^{117}$ Our law does not require intention on the part of the employer as an element essential to establishing discrimination. ${ }^{118}$ The burden of proof would then rest on the employer to show that it was not unfair discrimination.

\section{Justifying religious discrimination in the workplace}

Where differentiation amounts to discrimination on an unlisted ground the worker must also prove the unfairness thereof. ${ }^{119}$ Naturally, the distinction between direct and indirect discrimination is relevant at this point. It is not unfair to discriminate for reasons based on the inherent requirements of the job. ${ }^{120}$ An example of differentiation based on religion that would not constitute unfair discrimination is the inherent requirements of the job such as where a vacancy becomes available in a synagogue for the appointment of a rabbi. The differentiation cannot amount to unfair religious discrimination where the applicant practises non-Jewish religion as opposed to someone from the Jewish faith with the requisite Messianic Jewish Rabbinic qualifications. This example must arguably be distinguished from a situation where the work to be performed by the worker at a particular religious institution is of such a nature as to be considered "neutral" and that the worker's religious beliefs are irrelevant and unrelated to the inherent requirements of the job. An example would be the maintenance of outer buildings and gardens where the nature of work involves no religious responsibilities and is unaffected by the worker's religious beliefs. ${ }^{121}$ Since South African law does not offer a statutory definition of the crucial concept of "inherent requirements of the job", guidance must be sought as to the proper meaning thereof in terms of national and international case law.

\section{Limiting religious discrimination in the workplace}

It is true that where discrimination may be prevented from occurring it would be unfair of an employer not to take all reasonable steps to prevent same. What may an employer do proactively to prevent discrimination based on religion? In addition, the concept of reasonable accommodation will be analysed an evaluated. "Reasonable accommodation" is defined in the EEA as meaning "any modification or adjustment to a job or to the working environment that will enable a person from a designated group to have

${ }^{117}$ Van Niekerk et al Law@work 129 and 130 and the authorities referred to in the texts of fn 32-35.

${ }^{118}$ City Council of Pretoria v Walker 1998 (2) SA 363 (CC).

${ }^{119}$ Van Niekerk et al Law@work 135.

${ }^{120} \mathrm{~S} 6(2)(\mathrm{a})$ and (b) of the EEA. Etymology of the term "inherent requirement" of the job is Article 2 of C 111 ratified by South Africa. See Van Niekerk et al Law@work 138-139.

${ }^{121}$ An exception may of course arise where the religious institution or organisation is so orthodox in nature that it requires all its workers, irrespective of the degree of involvement in the running of the business of the organisation to be followers of the organisation's religious faith. See Clause 9.1 of the SACRRAF. 
access to or participate or advance in employment". ${ }^{122}$ Reference to a person from a designated group appears to confine the term to matters pertaining to affirmative action. ${ }^{123}$ This is underscored by the fact that the Code of Good Practice on the Employment of People with Disabilities ${ }^{124}$ makes express provision that employers should accommodate the needs of people with disabilities reasonably.

To what extent has reasonable accommodation been utilized by our courts in religious discrimination cases? ${ }^{126}$ Can this notion be said to be a juristic tool of assistance to our courts when endeavoring to balance the competing rights of parties to a dispute? In Dhlamini and others $v$ Green Four Security ${ }^{127}$ an additional enquiry was introduced into establishing whether unfair religious discrimination had taken place. Even if it could be established that being clean-shaven was an inherent requirement of the job, namely being a security guard, the court held that it could still amount to unfair discriminatory conduct on the part of the employer since the employer was obliged to accommodate the worker's religious beliefs reasonably unless it would result in undue hardship for the employer. ${ }^{128}$ This is a significant finding as it prima facie imposes an additional requirement for the employer to fulfil before the court would hold that the discrimination was not unfair.

In Strydom v NG Gemeente Moreleta Park, ${ }^{129}$ although distinguishable from the Dhlamini case in so far as the matter had to be decided by the Equality court with reference to PEPUDA and the Constitution, the question of what steps the respondent took that amounted to reasonable accommodation of diversification and thereby addressing disadvantages suffered from discrimination was raised. ${ }^{130}$

Moreover, in Department of Correctional Services $v$ POPCRU, ${ }^{131} 21$ members of the first respondent who worked as prison warders were dismissed on the basis that they refused to cut their dreadlocks. The dismissed employees insisted their hairstyles were consistent with their religious beliefs as Rastafarians and cutting it would infract their rights. They contended their dismissals were automatically unfair in terms of the LRA and unfair discrimination in terms of the EEA. Having established that differentiation took place on the listed ground of religion, the respondent

122 S 1.

${ }^{123}$ Dealt with in terms of Chapter III of the EEA.

124 Published under GN 1345 in GG 23702 of 2002-08-19.

125 In terms of clause 6.1.

${ }^{126}$ Clause 2.2 of the SACRRAF states that: "Every person has the right to have their religious beliefs reasonably accommodated." Ruan "Accommodating Respectful Religious Expression in the Workplace" 2008 Marquette LR 13.

127200611 BLLR 1074 (LC). In this case the applicants (security guards) who had been dismissed for refusing to shave their beards claimed they were religiously discriminated against.

128 1078C

${ }^{129} 200930$ ILJ 868 (EqC). This case had to do with a religious discrimination brought by the applicant against the church in terms of the provisions of PEPUDA.

130 Par 32

1312011 ZALAC. 
could not prove the discrimination to be fair in terms of any inherent job requirements. Murphy AJA went further ${ }^{132}$ by looking at the question of the fairness and justifiability of the differential treatment. The court found that considerations in determining fairness in the context of section 187(1)(f) were equally applicable in determining fairness under the EEA and PEPUDA. Unfairness under these provisions, according to Murphy AJA, concentrates upon, inter alia, whether reasonable steps have been taken to accommodate the diversity sought to be advanced and protected by the principle of non-discrimination or whether it could be accommodated in any less restrictive manner and still uphold the interests of the employer.

\section{5 APPLYING THE LEGAL TESTS}

\section{The correct test to determine the existence of unfair discrimination in a labour context}

The test set out ${ }^{133}$ in Harksen $v$ Lane was established in respect of determining whether section 21 of the Insolvency Act ${ }^{134}$ contravened the equality and discriminatory provisions of section $8^{135}$ of the Interim Constitution. ${ }^{136}$ It has been stated that Harksen, Prinsloo and the Hugo cases provide guidelines on interpreting violations of $s \quad 9$ of the Constitution. ${ }^{137}$ Govender correctly refers to forthcoming national legislation that would regulate the section 9 equality and non-discriminatory right. ${ }^{13}$

One would, however, have anticipated the learned author to make more critical reference to the provisions of the LRA ${ }^{139}$ that give effect to section 9 of the Constitution. Disputes concerning religious discrimination brought in terms of contraventions of the EEA or the LRA raise the critical question as to the appropriateness of the Harksen $v$ Lane test ("the Harksen test"). Numerous cases have relied on the Harksen test. ${ }^{140}$ In IMATU, Murphy AJ

\footnotetext{
${ }^{132}$ Par 37.

${ }^{133}$ Which appears from par 53 of the judgment by Goldstone J.

13424 of 1936.

${ }^{135}$ Now the substantive equivalent of s 9(1)-(5) of the Constitution.

${ }^{136} 200$ of 1993.

${ }^{137}$ Govender "The Equality Provision, Unfair Discrimination, and Affirmative Action" 1998 Indicator South Africa 79.

138 Taking into account that the EEA was effective 09 August 1999.

${ }^{139} \mathrm{Eg}, \mathrm{s}$ 187(1)(f).

${ }^{140}$ See, eg, Louw v Golden Arrow Bus Service (Pty) Ltd 1999 ZAZLC 66 par 19, where the issue before court was alleged race discrimination, brought in terms of the LRA framed as erstwhile unfair residual labour practices; NUMSA v Gabriels (Pty) Ltd 2002 ZALC 74 par 9, where the issue before court concerned wage differences as constituting alleged unfair discrimination on the basis of s 6(1) of the EEA; FAWU v Pets Products (Pty) Ltd 2000 ZALC 25 par 13, where the issue before court concerned payment to non-striking workers constituting alleged contravention of $s 5(1)$ non-discriminatory provisions of the LRA; and IMATU $v$ City of Cape Town 2005 ZALC 10 par 80, where the issue before the court was based on discrimination in terms of $s 6(1)$ of the EEA, the claimant alleging direct discrimination on the basis of disability resulting from diabetes mellitus.
} 
was emphatic that the Harksen test was "the appropriate test"141 to establishing unfair discrimination.

If the Harksen test is an appropriate test it cannot, it is submitted, be the panacea determinative of all discrimination disputes. Factors relevant to a religious discrimination dispute will be of no value in determining a discrimination dispute based on incapacity. It is noteworthy that cases referred to in this paper concerning religious discrimination, ${ }^{142}$ draw heavily on a duty of reasonable accommodation rather than an express adoption of the Harksen test. A caveat appears from POPCRU, where the court refers to fairness being presumed where discrimination on a listed ground is established. ${ }^{143}$ An overview of reported workplace religious discrimination disputes do not indicate that the Harksen test has been eschewed. On the other hand, whether the reasonable accommodation test addresses the issues adequately of deciding how and where to strike a suitable balance in religious discrimination disputes ${ }^{144}$ has also been mooted.

\section{Balancing religious group (associational) rights with competing rights}

Taylor $v$ Kurstag $\mathrm{NO}^{145}$ is authority for the associational right to freedom of religion enshrined in sections 31 and 18 of the Constitution and that freedom includes the right of others to exclude non-conformists and to require those who join an association to conform with its principles and rules. Express provision is made for the associational right to institutional freedom of religion in terms of the SACRRAF. ${ }^{146} \mathrm{~A}$ worker alleging religious discrimination on this basis would need to establish differential treatment amounting to discrimination on a listed ground. MEC for Education, Kwazulu-Natal $v$ Pillay ${ }^{147}$ concerned a claim of religious discrimination based on PEPUDA. Whilst the applicant schoolgirl was required to show differentiation that amounted to discrimination ${ }^{148}$ on a listed ground, namely religion, ${ }^{149}$ the respondent bore the onus of showing either that the conduct was not based on one of the prohibited grounds ${ }^{150}$ or that discrimination was fair. ${ }^{151}$ Fairness includes, but is not limited, to notions such as the fact that discrimination was necessary due to the intrinsic nature of the job ${ }^{152}$ and the

\footnotetext{
${ }^{141}$ Par 80. In the main it is clear that the court invoked the test of reasonable accommodation.

142 Namely, Dhlamini, Strydom, Taylor; Prince; Pillay; POPCRU and Kievits.

143 Par 32.

144 Benson 2008 Constitutional LR 298.

14520044 All SA 317 (W).

${ }^{146}$ Clause 9 and 9.1.

1472008 (1) SA 474 (CC).

$148 \mathrm{~S}$ 13(1) PEPUDA.

$149 \mathrm{~S} 8(\mathrm{~d})$.

$150 \mathrm{~S} \mathrm{13(b)}$.

$151 \mathrm{~S} 13(2)$

152 S 14(2)(c).
} 
extent to which the employer has taken steps that are reasonable in order to accommodate diversity ${ }^{15}$

In Prince $v$ President, Cape Law Society ${ }^{154}$ the applicant sought to be admitted as an attorney. His application was opposed by the Law Society on the basis that he was not a fit and proper person having two previous convictions relating to dagga and that Prince had expressly stated that he did not intend to desist from smoking the substance since it formed an essential part of his Rastafarian belief-system. Rastafarianism was found by the court in this instance as a religion entitled to be protected, however the right to freedom of religion is not absolute and members of a religious community may not determine for themselves which laws they will obey and which they will not. ${ }^{155}$ Case authority supports the fact that religious associations may expel members who fail to conform to their religious code of conduct, mode of dress and or culture. ${ }^{156}$ On the other hand, religious associations are also restrained from exercising and practising faith-based corporal punishment at schools. ${ }^{157}$

Neither the Pillay nor Prince cases involve workplace religious discrimination. ${ }^{158}$ Their relevance is germane to the right(s) which employer organizations and employers have in asserting their religious unity or identity as a collective whole to the fair exclusion of workers. Should this be tantamount to an employer who is entitled to set the standard by which employees are required to perform ${ }^{159}$ Setting a standard is distinguishable by the prerogative of management in the operational function of its business, whereas assertion of an associational right based on religion, is founded on the right to equality, human dignity and freedom of association. If this is the case, how then is a fair balance struck between the religious associational right and the right of an individual applicant job-seeker insistent upon applying for a position within a particular religious association? ${ }^{160} \mathrm{An}$ example is where the organization of a particular religion has administrative offices who insist upon its workers across the board, irrespective of the task they fulfil, to be members of the church whose affairs they administer. ${ }^{161}$ Another example pertains to trade unions. Although a trade union also has a right to freedom of association and the right to determine its own constitution and rules, ${ }^{162}$ with reference to what is fair ${ }^{163}$ the constitution of a trade union

${ }^{153} \mathrm{~S} 14(3)(\mathrm{i})$.

1542002 (2) SA 794 (CC).

155 In casu, the applicant attacked the constitutionality of the Drugs and Drug Trafficking Act 140 of 1992 as part of his claim that non-admission as an attorney was discriminatory.

${ }^{156}$ Currie and De Waal The Bill of Rights Handbook 440-443.

${ }^{157}$ See Christian Education South Africa v Minister of Education 20022 SA 794 (CC); and Currie and De Waal The Bill of Rights Handbook 441-442.

158 The Christian Education case is also distinguishable from workplace religious discrimination.

${ }^{159}$ Rustenburg Platinum Mines Ltd (Rustenburg Section) v CCMA 2006 SCA 115 (RSA) par 46.

${ }^{160}$ The right to freedom of religion in terms of $s 15$ of the Constitution, as read with the right to freedom of expression in terms of $\mathrm{s} 16$, does not, for obvious reasons, extend to advocacy of hatred based on religion which would constitute incitement to cause harm in terms of $s$ $16(2)(c)$.

${ }^{161}$ See clause 9.1 of the SACRRAF.

${ }^{162} \mathrm{~S} 8(\mathrm{a})(\mathrm{i})$ of the LRA.

${ }^{163} \mathrm{~S} 26(5)(\mathrm{b})$ of the LRA. 
may not discriminate unfairly and the LRA expressly lists religion as one of many other grounds such as gender or race that would result in an automatic unfair dismissal. ${ }^{164}$

One has to juxtapose the interests of various role players, namely religious organizations and a secular job applicant, alternatively a worker dismissed for failing to conform sufficiently to the employer's religious associational beliefs or further, alternatively, a worker unfairly discriminated against directly or indirectly by the employer on the basis of religion. One also has to decide whether on account of a public sector-based employment relationship, any factors relevant to the unique nature of the employment relationship or administrative-law requirements ${ }^{165}$ could justify limitations on the infringement of the right to equality and or freedom of association.

\section{Private and public sector employment relationships}

All employees, whether private or public, are deserving of equal protection under the Constitution, LRA and EEA. ${ }^{166}$ The preamble of the LRA and PAJA make these Acts submissive to constitutional imperatives imposed on the employment relationship in both the private and public sector. Religious discrimination in the public sector brings into play extraneous factors falling within the purview of PAJA. This warrants critically viewing religious discrimination in the workplace within the context of administrative-law principles in those cases where the action on the part of the state does constitute administrative action. ${ }^{167}$ In this context, the following issues may arise therefrom:

- To what extent is the exercise of public power in terms of section 33 of the Constitution ${ }^{168}$ or PAJA prevented from infringing upon the right to equality and freedom of association in so far as the right to religion is concerned? And

- in what manner, if any, does the principle of legality ${ }^{169}$ influence and regulate the exercise of public power to ensure respect for the right to equality and freedom of association in so far as the right to religion is concerned? ${ }^{170}$

${ }^{164} \mathrm{~S} 187(1)(\mathrm{f})$ of the LRA.

165 As discussed below.

166 The limited exclusions pertain to members of the National Defence; National Intelligence Agency; South African Secret Service; the South African National Academy of Intelligence; and members of COMSEC. See $s$ of the LRA and $s$ 4(3) of the EEA.

167 See Gcaba v Minister for Safety \& Security 2009 ZACC 26.

168 The right to just administrative action.

169 See Fedsure Life Assurance Ltd v Greater Johannesburg Metropolitan Council 1998 (2) SA 1115 (SCA); SARFU $\vee$ President of RSA 2000 (1) SA 1 (CC) par 140 and 148; $A A A$ Investments (Pty) Ltd v Micro Finance v Regulatory Council 2006 ZACC 9 (CC) par 39-41. See Hoexter "The Principle of Legality in South African Administrative Law" 2004 Macquarie LJ 165; and O'Regan "On the Reach of the Constitution and the Nature of Constitutional Jurisdiction" in Woolman and Bishop (eds) Constitutional Conversations 6375.

170 Significantly, clause 3.1 of SACRRF imposes a duty on the state to create a positive and safe environment for the exercise of religious freedom and moreover the state may not promote, favour or prejudice a particular faith, religion or conviction. 


\section{CANADA}

\section{Equality framework}

The Canadian Charter of Rights and Freedoms ${ }^{171}$ (the CCRF) provides for freedom of conscience and religion. ${ }^{172}$ Every individual is "equal under the law and has the right to the equal protection and benefit of laws without discrimination [based on] religion". ${ }^{173}$ The aforesaid is subject to a "reasonable" limitation clause consonant with limits in a "free and democratic society". ${ }^{174}$ Notably, the Canadian Human Rights Act ${ }^{175}$ (the CHRA) imposes a duty to accommodate. ${ }^{176}$ This latter duty is also expressed in the Canadian Employment Equity Act ${ }^{177}$ (the CEEA), but this legislation is Federal and applicable to certain industries. ${ }^{178}$ Non-discriminatory provisions that are catered for by virtue of the aforesaid are subject to the caveat of the occupational imperative of a bona fide occupational requirement (a BFOR), a "reasonable and justifiable defence" ${ }^{\text {"179 }}$ and considerations of reasonable accommodation.

\section{Mutual accommodation}

Population diversity in Canada has translated into burgeoning cultural, ethnic and religious workplace conflict. ${ }^{181}$ This has been addressed in terms of the equality-based legislation. ${ }^{182}$ Protection against religious discrimination in the workplace is provided by legislation of various federal governments. These equality laws may vary but are ultimately subject to the CCRF and CHRA. ${ }^{183}$

\footnotetext{
${ }^{171}$ Referred to as the Canadian Constitution Act 1982.

172 S 2(a). See also Van Praagh "Identity's Importance: Reflections of - and on - Diversity" 2001 Canadian Bar Review 605608.

${ }^{173} \mathrm{~S} 15(1)$.

${ }^{174} \mathrm{~S} 1$. Similar to the limitation clause contained in s 36 of the South African Bill of Rights.

${ }^{175}$ Of 1985.

${ }^{176} \mathrm{~S} 15(2)$ of the CHRA requires establishment [proof] that accommodation would impose undue hardship on the person required to accommodate regard being had to health, safety and cost, whereas $s 5(b)$ of the CEEA imposes a duty on the employer of reasonable accommodation of designated persons which includes "visible minorities". It would not be farfetched to conceive a situation of a worker claiming to fall within the ambit of visible minority on religious grounds.

177 Of 1995.

${ }^{178}$ Eg, banks, railroads, airlines and the maritime industry. It has also been the subject matter of controversial debate in terms of the extent to which it rigidifies and sanctions discrimination in respect of favour of designated individuals. For further reading see: Fridman "Ontario's Employment Equity Legislation: An Act Not to Follow" 1995 Agenda 455 463; and Author Unknown "The Politics of Preference: A Catalogue of Criticisms of Employee Equity" http://www.safs.ca/meritdiversity/catalogofcriticism.pdf (accessed 2012-09-26).

${ }^{179}$ Vickers Religious Freedom, Religious Discrimination and the Workplace (2008) 196.

180 Ibid.

${ }^{181}$ Author Unknown "Cultural Accommodation in the Workplace: Tips and Practices" September 2010 HRPA OTTAWA Magazine 22.

182 Moon Law and Religious Pluralism in Canada (2008) 2.

${ }^{183}$ Vickers Religious Freedom 195.
} 
Debate has also ensued ${ }^{184}$ as to the extent a BFOR may undermine the individual right ${ }^{185}$ and supress the advancement of pluralism. Crystallization of the current position of the common law is set out below.

In Ontario Human Rights Commission v Simpsons-Sears Ltd (O'Malley) ${ }^{186}$ an employer was obliged to accommodate an employee who during her employment converted to the Seventh-Day Adventist faith requiring her to be absent from work from Friday evenings and Saturdays, unless the employer could show accommodation would result in undue hardship. The court in Alberta Human Rights Commission v Central Alberta Dairy Pool ${ }^{187}$ held that an employee who had become a member of the World-wide Church of God which precluded him from attending work on Mondays would be adversely discriminated against even if there is a BFOR unless the employer is able to discharge the onus of showing accommodation would impose undue hardship regard being had to a variety of factors. ${ }^{188}$ Where, on the face of it, a BFOR is discriminatory against an employee's religion, the employer would still be required to prove a rational link between the discriminatory rule and the purpose of the job in order to show that the standard is imposed in good faith solely as a "work-based purpose". ${ }^{18}$

An employer may still be required to endure a hardship in accommodating the employee's religion, provided it is not "undue". ${ }^{190}$ These duties on the employer has been somewhat mitigated by extending accommodation to the employee as evidenced in Central Okanagan School District No $23 \mathrm{v}$ Renaud. ${ }^{191}$ The unionized employee who was a member of the Seventh Day Adventist objected to working shifts from sundown-Friday-sundownSaturday. The recommendation by the employer that Renaud work a Sunday to Thursday shift was rejected since same would have been contrary the collective agreement. This, the court viewed, as "impeding the reasonable efforts of an employer to accommodate" ${ }^{, 192}$ essentially finding that there was a mutual duty of accommodation on both parties to seek accommodation. ${ }^{193}$

Vickers is correct, it is submitted, in advocating that the mutual duty of accommodation can be lauded for "achieving a reasonable balance between [employer and employee]". ${ }^{194}$ Such multi-diversity, non-exclusivity approach $^{195}$ has developed Canadian jurisprudence positively in the

\footnotetext{
${ }^{184}$ Sossin "God at Work: Religion in the Workplace and the Limits of Pluralism in Canada" 2009 Comparative Labor Law and Policy Journal 485 494-497.

${ }^{185}$ Against discrimination on the basis of religion as envisage in $\mathrm{s} 15(1)$.

18619852 S.C.R. 536 (Can).

18719902 S.C.R. 517 (Can).

188 Sossin 2009 Comparative Labor Law and Policy Journal 497.

${ }^{189}$ Vickers Religious Freedom 198. See also the case referred to by the author.

190 Ibid.

19119922 S.C.R. 970 (Can).

192 Canadian Human Rights Commission: Resources http://www.chrc-ccdp.ca/discrimination/ dpfa_uppt/page6-eng.aspx (accessed 2012-09-25).

${ }^{193}$ Vickers Religious Freedom 198-199.

${ }^{194}$ Vickers Religious Freedom 205.

195 Buckingham "Advocacy for Religious Freedom in Canadian Law" 2011 International Journal for Religious Freedom 65.
} 
direction of tolerance and embracement of diversity in the interests of maintaining a harmonious working environment that also holds good for sound community interests. Moreover, the reference of Canadian courts to international articles such as the Charter of the United Nations and foreign jurisprudence has heightened a global awareness of religious freedom and intolerance against discrimination.

\section{CONCLUDING REMARKS}

Legal obligations and rights arise from the pluralistic religious and sectarian milieu of the workplace. In the strife for a harmonious working environment the even-handedness of appointing the employer custodian of balancing these conflicting dynamics must be challenged. The intrinsic personal nature of religion demands meaningful engagement by both parties - employee and employer - to attempt to accommodate differences ${ }^{197}$ mutually under the banner of diversity.

Non co-operative approaches can result in victimization ${ }^{198}$ as much as hegemony. ${ }^{199}$ The assertion that sexual orientation, for example, is as much part of a person's innate being ${ }^{200}$ as is their gender or race, something with which they are born and over which they have no election, as opposed to religion which is socially or culturally informed, ${ }^{201}$ makes no difference to the imperative of addressing religious diversity in the workplace which is mirrored in a diverse number of religious faiths. ${ }^{202}$ In our constitutional dispensation diversification and tolerance thereof is a peremptory requirement as captured by the statement that: "We need to create an environment that brings about unity, embraces our diversity, and protects the idea of a rainbow nation." ${ }^{203}$ In Fourie, Sachs J stated:

“[...] Equality means equal concern and respect across difference. It does not presuppose the elimination or suppression of difference. Respect for human rights requires the affirmation of self, not the denial of self [...] but an acknowledgement and acceptance of difference [...] difference should not be

${ }^{196} \mathrm{Ibid}$. The recent establishment of the Office of Religious Freedom in 2011 under the aegis of the Department Foreign Affairs has brooked considerable criticism. See, eg, Author Unknown "New 'Religious Freedom' Office Raises Questions" http://www.cbc.ca/news/ canada/story/2011/10/03/pol-office-religious-freedom.html (accessed 2011-09-24); Tapper "Does the Office of Religious Freedom have any Teeth?" http://www.thestar.com/news/ canada/article/1119007--does-the-office-of-religious-freedom-have-any-teeth (accessed 2012-09-26); and Worthington “Just Leave it Alone: Canadians Don't Need an Office of Religious Freedom" http://www.torontosun.com/2012/09/14/just-leave-it-alone-canadiansdont-need-an-office-of-religious-freedom (accessed 2012-09-26).

197 In the absence of undue hardship or rational nexus with the BFOR.

${ }^{198}$ In the sense of where one is discriminated against on the basis of one's religious beliefs.

${ }^{199}$ See Gunn 210 in fn 24 above.

${ }^{200}$ Ruan 2008 Marquette $L R 7$ fn 20.

${ }^{201}$ Benson 2008 Constitutional LR 309.

${ }^{202}$ Benson 2008 Constitutional LR 302; and the dicta of the Canadian court in the case of Chamberlain v Surrey School Board (2000) 80 BCLR (3d) 181 (CA) par 137.

${ }^{203}$ Mokoa "Law the Key that Opens the Door to Unity in Diversity" 3 October 2011 The Times 14. 
the basis for exclusion, marginalisation and stigma. At best, it celebrates the vitality that difference brings to any society".

Using the mutual accommodation as articulated in Canadian law is not out of kilter with the reciprocity of fairness between employee and employer as firmly established by the court in NEHAWU. It is thus incumbent on both parties to create an environment of mutual respect and accommodation of diversity. A jostling of rights creatively played in accordance with mutual accommodation will give creative impetus to the theme and score of tolerance of diversity ...

${ }^{204}$ Par 60. 